\title{
Recommender Systems for Technology Enhanced Learning
}

Citation for published version (APA):

Manouselis, N., Verbert, K., Drachsler, H., \& Santos, O. C. (Eds.) (2014). Recommender Systems for Technology Enhanced Learning: Research Trends \& Applications. (1 ed.) Springer. https://doi.org/10.1007/9781-4939-0530-0

\section{DOI:}

10.1007/978-1-4939-0530-0

Document status and date:

Published: 01/01/2014

Document Version:

Other version

Document license:

CC BY-NC-SA

Please check the document version of this publication:

- A submitted manuscript is the version of the article upon submission and before peer-review. There can be important differences between the submitted version and the official published version of record. People interested in the research are advised to contact the author for the final version of the publication, or visit the DOI to the publisher's website.

- The final author version and the galley proof are versions of the publication after peer review.

- The final published version features the final layout of the paper including the volume, issue and page numbers.

Link to publication

\section{General rights}

Copyright and moral rights for the publications made accessible in the public portal are retained by the authors and/or other copyright owners and it is a condition of accessing publications that users recognise and abide by the legal requirements associated with these rights.

- Users may download and print one copy of any publication from the public portal for the purpose of private study or research.

- You may not further distribute the material or use it for any profit-making activity or commercial gain

- You may freely distribute the URL identifying the publication in the public portal.

If the publication is distributed under the terms of Article 25fa of the Dutch Copyright Act, indicated by the "Taverne" license above, please follow below link for the End User Agreement:

https://www.ou.nl/taverne-agreement

Take down policy

If you believe that this document breaches copyright please contact us at:

pure-support@ou.nl

providing details and we will investigate your claim.

Downloaded from https://research.ou.nl/ on date: 26 Apr. 2023 


\section{Preface}

Technology-enhanced learning (TEL) aims to design, develop, and test sociotechnical innovations that will support and enhance learning practices of both individuals and organisations. It is an application domain that generally addresses all types of technology research and development aiming to support teaching and learning activities, and considers meta-cognitive and reflective skills such as selfmanagement, self-motivation, and effective informal and self-regulated learning. It was in 2007 when our first efforts to create opportunities for researchers working on topics related to recommender systems for TEL found their way in workshops like the Workshop on Social Information Retrieval for Technology Enhanced Learning (SIRTEL), the Workshop on Context-Aware Recommendation for Learning, and the Workshop Towards User Modelling and Adaptive Systems for All (TUMAS-A).

Still, it was only in 2010 when a really rare opportunity rose: during the same week of September and at the same location (Barcelona, Spain), two very prestigious and very relevant events (the fourth ACM Conference on Recommender Systems and the fifth European Conference on Technology Enhanced Learning) took place, giving us the chance to bring the two communities together. And so we did, by organising a joint event called the 1st Workshop on Recommender Systems for Technology Enhanced Learning (RecSysTEL).

Since then, lots of things have happened to mainstream educational applications in recommender systems' research. The most important achievement is an initial pool of datasets that have been collected and can be used to compare the outcomes of different TEL Recommender Systems to create a body of knowledge about the effects of different algorithms on learners. Furthermore, running research projects like Open Discovery Space ${ }^{1}$ and LinkedUp ${ }^{2}$ aim to create a publicly accessible Linked Data cloud ${ }^{3}$ that can be used as a reference dataset for RecSysTEL research. Along these infrastructure improvements various scientific events and publications

\footnotetext{
${ }^{1}$ www.opendiscoveryspace.eu/

${ }^{2}$ www.linkedup-project.eu/

${ }^{3}$ http://data.linkededucation.org/linkedup/catalog/
} 
have been realised. The most relevant are the organisation of subsequent editions of the RecSysTEL workshop with bi-annual periodicity; authoring a review article for the Recommender Systems Handbook; expanding it to an introductory handbook on Recommender Systems for Learning; and contributing (as co-editors or as authors) to several relevant Special Issues in scientific journals and specialised books.

We thought that this is a good time to build upon this previous experience and to collect some state-of-the-art contributions to a volume that will give a fresh view of the status of this area. Our interest was to collect a representative sample of highquality manuscripts that will illustrate some important research trends, identify key challenges and demonstrate some innovative applications. This volume is the result of an open call that helped us collect, peer-review, select and propose for publication 14 articles (out of 49 proposed works; $29 \%$ acceptance rate) that give a very good picture of the current status of research in recommender systems for TEL. The first four chapters (Karampiperis et al.; Cenichel et al.; Dietze et al.; Bienkowski and Klo) deal with user and item data that can be used to support recommendation systems and scenarios. The next four (Hulpus et al.; Santos et al.; Schwind and Buder; Tang et al.) focus on innovative methods and techniques for recommendation purposes. And the last six (Fazeli et al.; Bielikova et al.; Nowakowski et al.; Fernandez et al.; Sie et al.; Petertonkoker et al.) present examples of educational platforms and tools where recommendations are incorporated.

The bibliography covered by this book is available in an open group created at the Mendeley research platform ${ }^{4}$ and will continue to be enriched with additional references. We would like to encourage the reader to sign up for this group and to connect to the community of people working on these topics, gaining access to the collected bibliography but also contributing pointers to new relevant publications within this very fast developing domain.

We hope that you will enjoy reading this volume as much as we enjoyed editing it.

Athens, Greece

Heerlen, The Netherlands

Leuven, Belgium

Madrid, Spain
Nikos Manouselis

Hendrik Drachsler

Katrien Verbert

Olga C. Santos

\footnotetext{
${ }^{4}$ http://www.mendeley.com/groups/1969281/recommender-systems-for-learning/
} 


\section{Contents}

\section{Part I User and Item Data}

Collaborative Filtering Recommendation

of Educational Content in Social Environments Utilizing

Sentiment Analysis Techniques.

Pythagoras Karampiperis, Antonis Koukourikos, and Giannis Stoitsis

Towards Automated Evaluation of Learning Resources

Inside Repositories

Cristian Cechinel, Sandro da Silva Camargo,

Salvador Sánchez-Alonso, and Miguel-Ángel Sicilia

A Survey on Linked Data and the Social Web

as Facilitators for TEL Recommender Systems

Stefan Dietze, Hendrik Drachsler, and Daniela Giordano

The Learning Registry: Applying Social Metadata

for Learning Resource Recommendations.

Marie Bienkowski and James Klo

\section{Part II Innovative Methods and Techniques}

A Framework for Personalised Learning-Plan

Recommendations in Game-Based Learning

Ioana Hulpuş, Conor Hayes, and Manuel Oliveira Fradinho

An Approach for an Affective Educational

Recommendation Model.

Olga C. Santos, Jesus G. Boticario, and Ángeles Manjarrés-Riesco

The Case for Preference-Inconsistent Recommendations

Christina Schwind and Jürgen Buder 
Further Thoughts on Context-Aware Paper

Recommendations for Education

Tiffany Y. Tang, Pinata Winoto, and Gordon McCalla

\section{Part III Platforms and Tools}

Towards a Social Trust-Aware Recommender for Teachers

Soude Fazeli, Hendrik Drachsler, Francis Brouns, and Peter Sloep

ALEF: From Application to Platform for Adaptive Collaborative

Learning

Mária Bieliková, Marián Šimko, Michal Barla, Jozef Tvarožek,

Martin Labaj, Róbert Móro, Ivan Srba, and Jakub Ševcech

Two Recommending Strategies to Enhance Online

Presence in Personal Learning Environments.

Samuel Nowakowski, Ivana Ognjanović, Monique Grandbastien, Jelena Jovanovic, and Ramo Šendelj

Recommendations from Heterogeneous Sources in a Technology Enhanced Learning Ecosystem

Alejandro Fernández, Mojisola Erdt, Ivan Dackiewicz, and Christoph Rensing

COCOON CORE: CO-author REcommendations

Based on Betweenness Centrality and Interest Similarity

Rory L.L. Sie, Bart Jan van Engelen, Marlies Bitter-Rijpkema, and Peter B. Sloep

Scientific Recommendations to Enhance Scholarly

Awareness and Foster Collaboration.

Jan Petertonkoker, Wolfgang Reinhardt, Junaid Surve, and Pragati Sureka 


\section{丵 Springer}

http://www.springer.com/978-1-4939-0529-4

Recommender Systems for Technology Enhanced Learning

Research Trends and Applications

Manouselis, N.; Drachsler, H.; Verbert, K.; Santos, O.C.

(Eds.)

2014, XIV, 306 p. 67 illus., Hardcover

ISBN: 978-1-4939-0529-4 